\title{
Social structure and economic performance: the case of organic banana farmers in the vale do Ribeira region, in Brazil
}

\begin{abstract}
Organic production is an essential strategy for a better food security in contemporary society. However, this mode of agrarian production is not present in a massive manner on important regions of food production around the world. For instance, in Vale do Ribeira, the biggest banana producer region in Brazil, organic farming represents only $0,4 \%$ of total banana output. An explanatory fieldwork on the local permitted to state that organic farmers face several challenges to implement a full organic production system. Therefore, our main goal with the present article is to enlighten which are the main difficulties for the full implementation of this mode of production. Our main hypothesis is that barriers to access local food markets represents the main challenge for organic producers in the Vale do Ribeira, compromising its production system sustainability in the long term. In order to test such hypothesis, we conducted both a quantitative and qualitative analysis of eight different banana producers-four conventional, and four organic producers, and also an agronomic analysis of 15 banana plants in one hectare in each propriety, in order to have all agronomic parameters needed for an analysis of their farming systems. By ranking the main difficulties cited by banana farmers and conducting a multivariate analysis of the agronomic parameters, our findings show that barriers to participate on local food markets are the main root of secondary problems, such as the soil fertility, sigatoka and other plagues. We conclude our article by defending a systematic policy, both from governmental and from nongovernmental agencies, to include local organic farmers on responsive food chains.
\end{abstract}

Volume 3 Issue 2 - 2019

\section{Frizo Cesar,' Frizo Pedro, ${ }^{2}$ Khatounian Carlos, ${ }^{3}$ Silva Simone ${ }^{3}$}

'MA in Crop Science, Luiz de Queiroz College of Agriculture (ESALQ-USP), Brasil

${ }^{2} \mathrm{MA}$ in Sociology, Federal University of Rio Grande do Sul (UFRGS), Brasil

3Professor at the Crop Science Department, Escola Superior de Agricultura “Luiz de Queiroz" (ESALQ-USP), Brasil

Correspondence: Frizo Pedro, 2MA in Sociology, Federal University of Rio Grande do Sul (UFRGS), Brasil,

Email pedro.frizo@gmail.com

Received: September 28, 2017 | Published: April 08, 2019

\section{Introduction}

When one faces the main challenges of contemporary agriculture in a global scale, the fundamental problem that emerges from such analysis is that conventional agriculture is not sustainable on the long term, as it deals with the natural biome on an industrial logics without taking into consideration its biological cycles (carbon, nitrogen, potassium and other elements). In this sense, due to its extensive mode of production, conventional agriculture is often characterized by an energetic unbalance, consuming more energy than the total energy produced with its harvest. On the other hand, organic agriculture presents itself as an alternative for the extensive and predatory method of conventional productive procedures, conciliating productivity with the mitigation of the environmental impacts of agriculture, such as environmental degradation, losses on biological diversity, and erosion of the ecological basis. In this sense, taken as one of the most efficient strategies to achieve a better food security, organic production also has a decisive role within the agroecology field and, therefore, on the conservation of ecosystems. ${ }^{1,2}$ However, organic production brings with itself several challenges for its full implementation, both technical, managerial and commercial ones. These challenges are materialized by witnessing the rates of organic agriculture implementation in different regions of the world. As one may notice on the Table below, organic production still seizes a low representability on the total amount produced on countries with different levels of income (Table 1).
Table I Country's organic farming share on the total agrarian output

\begin{tabular}{ll}
\hline Country & Participation on total \\
\hline Austria & $19,50 \%$ \\
Sweden & $16,30 \%$ \\
Portugal & $8,10 \%$ \\
Uruguay & $6,30 \%$ \\
Argentina & $2,30 \%$ \\
Mexico & $2,30 \%$ \\
USA & $0,64 \%$ \\
Brazil & $0,27 \%$ \\
\hline
\end{tabular}

Source: Research Institute of Organic Agriculture,26 2015.

Brazil, for instance, appears as a departure point for comprehending organic systems implementation, once the representation of this agrarian practice is minimum there. According to the Table above, when compared to other important food producers around the world, we can see that organic production representability in Brazil national production is the smallest one. In this country, challenges for organic production become even more evident if we analyze, for instance, the current conjecture of banana production in the Vale do Ribeira region, in São Paulo state -the main banana producer region in Brazil. According to data published by Instituto Brasileiro de Geografia e Estatística, ${ }^{3}$ there are only 14 organic banana producers in the whole 
territory, while in parallel exist there more than 3.000 conventional producers in the same region. ${ }^{4}$ Vale do Ribeira is a region that comprehends the south part of São Paulo state, as well as the northeast of Paraná state-a region where the Ribeira river flows until it reaches the Atlantic ocean. Its hydrographical basin hosts a great diversity in terms of mountainous relief, going from the lower parts on the river outskirts until the Serra do Mar-an extensive composition of mountains that split the Planalto Paulista from the coast. Due to the tropical climate and to such great diversity of altitudes, Vale do Ribeira exhibits an expressive rate of biodiversity in terms of flora and fauna, hosting more than 10.000 species, as the Atlantic rainforest covers different types of geographical spaces. In terms of social aspects, the region hosts the main indigenous and quilombolas groups' lands of São Paulo state, as well as high indexes of rural poverty and low indexes of Human Development. ${ }^{5,6}$

Taken as one of the main economic activities of its rural population, conventional banana production summed efforts in increasing the rate of deforestation in this region. Notwithstanding, banana production is linked with important processes of environmental degradation around the globe, featuring as a cultivation that yields low income for its producers and high rates of individual contamination by pesticides. ${ }^{7,8}$ In light of this scenario, organic agriculture presents itself as a feasible option for sustainable rural development, a reduction of environmental impacts and a better food security. $1,2,9$ However, through an explanatory visit on this region, we witnessed that small-mid rural enterprises faces several challenges to implement this method of production. As a result, is our goal to fully understand why organic banana production has such low rate of participation on the total amount of banana production in the Vale do Ribeira region.

Being a heterodox mode of production in the local market, one can understand organic banana production as an attempt to challenge the paradigmatic functioning of the local agrarian economy. In this sense, in terms of unit of analysis, the present study is aiming to understand the barriers posed for the emergence of new economic orders, focusing specifically on measuring and identifying the lack of resources that avoid efficient strategies for establishing a sustainable and perennial banana organic mode of production and commercialization. In this way, the New Economic Sociology demonstrates to be a valuable theoretical approach for empirical cases like the one brought into analysis on this article. Its main authors tend to focus on how individuals and organizations struggle among themselves for establishing a dominant order on markets, mobilizing different types of resources they have on hands in order to promote control on the economic field. ${ }^{10}$ In this sense, capital, whether is economic, social or cultural, is crucial in defining the probabilities that a certain group of individuals or organizations have to promote control de facto. Among a very broad group of authors who developed such kind of analytical approach, we understand Pierre Bourdieu's writings as the imminent departure point towards an understanding of this kind for the empirical case presented in this article.

Bourdieu $^{11,12}$ is one of the most eminent figures on Field Theory, with a broad application on Social Sciences. However, the main theoretical incongruence usually committed in theoretical and empirical studies that follow his approach is to take his concepts in a sole manner. Instead, one has to concede a dialectical and a relational approach to his three main concepts: 'habitus', 'capital' and 'field'. ${ }^{13}$ In this sense, investigations aligned with his Field Theory propositions should not focus on the agent per se, but instead on the position that it occupies inside the field. Such position is consolidated from a specific composition of economic, social, cultural and symbolic capital detained by the agent. ${ }^{11}$ Therefore, the field is permeated with multiple positions due to multiple forms of capital distribution among agents. The economic realm is a social field embedded in socio-economic strata, as well as in struggles for power and interests. ${ }^{12}$ Action plans to reorder the existing functioning dynamics might be counterpointed and, more often than any other outcome, mitigated by individuals and organizations positioned on the top of the strata - i.e., the dominant/ incumbent actors. ${ }^{10,14}$ Due to a higher and broader composition of capital - whether economic, social, cultural or symbolic capital, the probability of the dominant part to reproduce the existing order is much higher than the probability of the dominated strata to transform it. On other moments, the structure of the economic field might be so rigid that depth internal transformations are very unlikely, even though external crisis or external participation occur. This conjuncture motivates what some calls the edification of "market niches" 15 inside the economic field itself.

Market niches are delineated spaces within the economic realm where challengers develop new modes of production and ways of distribution, avoiding challenging in a direct way the dominant actors and the established economic practices. Strategic actors may act in order to edify market niches if they realize that a complete transformation of the economic field is unlikely due to the established matrix of capital distribution and domination structure. ${ }^{10}$ Such structures are consolidated in order to sustain unequal competition among actors, and market niches is a feasible strategy when reordering them is an unlikely process. From niches, individuals and organizations might sustain new economic practices and increase their global composition of capital through time. Niches, in that sense, are places where new proposals are possible and developed, as well as spheres that might provide the necessary time for individuals and organizations to accumulate the necessary capital and expertise to challenge the existing order of practices, institutions, and power structure within the economic field.

Therefore, organic production can be theoretically understood as a strategy devised by small-mid rural enterprises to find their marketplace (i.e., niche) in a competitive agriculture sector (i.e., economic field), which is marked by intense uses of agrochemicals, machinery and paid labor - factors that lower paradigmatic rural producers' cost of selling and increasing their competitiveness. On the coming section, we shall briefly explore the mobilized methods for collecting data on our field research. Following that, we present the main results and its following discussions about the social construction of organic production and commercial structures. We finished the present article by showing the main findings, as well as by exploring few limitations and possibilities for future research topics. In order to understand the main obstacles for organic banana production and commercialization in the Vale do Ribeira region, we conducted the present research according to the main assumptions of the farming systems approach, described in details at Cochet, ${ }^{16}$ Dufumier ${ }^{17}$ Khatounian ${ }^{18}$ and Mazoyer. ${ }^{19}$ Such assumption can be resumed in the following manner: we analyze the agrarian activity not only on its internal dimensions but also on its social interactions with the economic and cultural structure on where it is embedded. In other words, we shall not focus exclusively on the technical practices of rural producers, but also on the geographical conditions and the power and labor relations in which they are subject. For identifying the organic proprieties analyzed throughout our research, we used 
the information available at the Agriculture Ministry (Ministério da Agricultura) website, where is listed all certified organic producers in any region in Brazil. The collected data was crossed with data available by few organic certification companies. We did that in order to assure that organic producers listed on the Agriculture Ministry website are certified proprieties. As a result, we identified 81 certified organic proprieties in the Vale do Ribeira region, but just few of them were banana farms - only 14 . After the identification of the organic proprieties, an exploratory visit was conducted in all of them. By the end of this period, four of them were selected for the execution of the planned methodology. In order to compare the main agronomic findings collected in the soil and plant analysis on organic proprieties, we chose other four conventional proprieties. Therefore, by the end of the selection process, we have four conventional proprieties and four certified organic proprieties.

Having established the research sample, we conducted (I) an agronomic analysis with 15 banana plants within one hectare of each propriety and (II) an interview with the owners of the selected proprieties in order to formulate a diagnostic about the production and commercialization system of these properties. Interview was conducted not only one time but also several occasions throughout the total amount of five visitations on these proprieties. On free interviews, we stimulated natural responses, in order to seize the issues that interviewees judged more important in regards to the management of their proprieties. This technique allowed us to picture a general view about the most relevant aspects of banana production and distribution in the region. In addition, free interviews were conducted not only with banana farmers, but also with important agents within the agriculture sector in the region. Therefore, agents of national and state government, non-profit organizations and intermediaries were interviewed too (more information regarding the agents that were interviewed can be found on the attachments section).

However, free interviews were used only in the first field trip. In the four subsequent ones, we conducted semi-structured interviews only with selected banana farmers, in order to explore the most we could of a certain group of themes, which were the following ones:

- participation on markets and commercialization instruments mobilized by organic banana farmers;

- management of the agricultural system fertility, exploring practices of soil recovery and necessities of buying chemical inputs;

- organic instruments for the management of antagonistic organisms;

- $\quad$ organization of the social relations of production (utilization of family labor force, sexual division of labor within the propriety and dependence rates of intermediaries for distribution);

- evaluation of the productive system efficiency and identification of desired changes within the propriety functioning.

Through this method, we encouraged interviewees to rank the problems and the main challenges to reach an efficient operation of their agricultural systems. Using the methodology described at Rodrigues et al. (1997), the proprietor had to rank, from zero to ten, how problematic a certain issue represent for an efficient operation of its agricultural system. "Zero" would be given for an issue that represents a minimum problem, whereas "ten" would be given for a topic that represents an extremely problematic issue. On the second moment, we proceeded with an agronomic analysis on the total amount of eight selected proprieties. This procedure was conceived in order to reach a better comprehension of production systems, their indices of brocas and Sigatokas - the most common kinds of plagues in banana farms in the Vale do Ribeira -, productivity and soil fertility. By the end of this part, we could identify which of these factors are determinant to segregate conventional and organic proprieties. In terms of selected cases for the multivariate analysis, we selected a set of 15 banana plants on each rural producer, from where we collected the agronomic parameters. Such procedure was established according to Nokoe and Ortiz (1998), who recommend a sample of 15 plants for each selected productive system.

Such distinction among different productive systems was possible due to a multivariate analysis through the Principal Component Analysis (PCA). In this study, the principal components for the variables were obtained by the correlation matrix rather than the covariance matrix modeling, and the scale effects of variables with high variance were avoided. To evaluate the variation of agronomic parameters between organic production and conventional production we performed a per mutational non-parametric multivariate analysis ${ }^{20}$ and a multivariate analysis ${ }^{21}$ using distance matrices.

\section{Results \& discussion}

As one can notice in the Figure below that Sigatoka is the main problem for banana cultivation according to conventional producers, while access to markets is understood as the biggest challenge for organic producers in the Vale do Ribeira region. However, Sigatoka also reveals to be a concerning issue for organic producers, as it occupies the second position, with a score of approximately five points. Finally, fertility appears in the third position and as a significant concern among organic producers, with a score of approximately three points. On the other side, in the agronomic principal component analysis, as it is shown on the Figure below, the rate of severity of Sigatoka in banana crops is the main agronomic feature that differentiates conventional producers from the organic ones. The latter appears with higher indices of Sigatoka occurrence than conventional producers, who control the plague mainly through the utilization of pesticides. Such finding challenges the problem posed on the ranking results, as conventional producers ranked this plague as the main challenge, even though they are less affected by it when compared to organic producers (Table 2). ${ }^{21}$

On the other hand, according to the image above, we may observe a significant division between the two productive modes, with one group positioned on the right side and the other one on the left margin. Such horizontal dispersion is the first component of analysis, which accounts for $20 \%$ of the variation. ${ }^{22}$ In this sense, the mains vectors of horizontal differentiation are Sigatoka severity, the number of functional leaves and the weight of banana bunches. These are the most important parameters in terms of explanation of the rate of variation in the main component. If we take into consideration that the number of functional leaves is indirectly affected by Sigatoka, then we can understand that this plague is indeed the main factor of relevance of separation among conventional and organic banana production groups. It is not surprisingly that access to market appears as the main challenge for organic producers. Such lack of access it is explained, most of all, due to a dearth amount of instruments, equipment and 
resources to connect with distribution channels. First of all, organic producers do not have full access of internet, having to move to a cyber store in the nearby city to use online services. ${ }^{23-25}$ Secondly, none of them has access to telephones and, finally, three of four of the organic producers do not have mail access on their proprieties (Table 3). These features exemplifies the reduced probability to establish social ties with institutional supporters, such as centers of commercialization, public calls for food acquisition (such as the Programa de Aquisição de Alimentos and the Programa Nacional de Alimentação Escolar) and to participate on meetings and reunions of local rural associations (Table 4).

Table 2 Farmer, type of farming and Sigatoka severity median. Ribeira valley, 2014

\begin{tabular}{lll}
\hline $\begin{array}{l}\text { Banana Producer (Type of } \\
\text { Farming) }\end{array}$ & Sigatoka Severity & Median \\
\hline 4 (Organic) & 47,9 & $\mathrm{a}$ \\
2 (Organic) & 46,6 & $\mathrm{a}$ \\
3 (Organic) & 44,4 & $\mathrm{a}$ \\
I (Organic) & 43,3 & $\mathrm{ab}$ \\
5 (Conventional) & 37 & $\mathrm{bc}$ \\
6 (Organic non-certified) & 33,3 & $\mathrm{~cd}$ \\
7 (Convencional) & 31,5 & $\mathrm{~d}$ \\
8 (Conventional) & 27,8 & $\mathrm{~d}$ \\
\hline
\end{tabular}

*The medians followed by same letter do not differ statistically by the MannWhitney test. We used Kruskal-Wallis test for the comparison of more than two independent groups, while we mobilized the Mann-Whitney test in order to compare two groups.

Table 3 Main features of analyzed banana farmers in the Vale do Ribeira, ${ }^{31}$ 2014

\begin{tabular}{|c|c|c|c|c|}
\hline Farmer & $\begin{array}{l}\text { Type of } \\
\text { production }\end{array}$ & $\begin{array}{l}\text { Area of } \\
\text { cultivation } \\
\text { (hectar) }\end{array}$ & City & $\begin{array}{l}\text { Variety of } \\
\text { banana }\end{array}$ \\
\hline I & $\begin{array}{l}\text { Certified } \\
\text { organic }\end{array}$ & 2,8 & Eldorado & $\begin{array}{l}\text { Nanicão, Prata, } \\
\text { Prata Catarina }\end{array}$ \\
\hline 2 & $\begin{array}{l}\text { Certified } \\
\text { organic }\end{array}$ & 3,0 & Cajati & Prata \\
\hline 3 & $\begin{array}{l}\text { Certified } \\
\text { organic }\end{array}$ & $\mathrm{I}, \mathrm{I}$ & Eldorado & $\begin{array}{l}\text { Nanicão, Prata, } \\
\text { Prata Catarina }\end{array}$ \\
\hline 4 & $\begin{array}{l}\text { Certified } \\
\text { organic }\end{array}$ & $\mathrm{I}, 3$ & Eldorado & $\begin{array}{l}\text { Nanicão, Prata, } \\
\text { Terra, São } \\
\text { Tomé,Vinagre } \\
\text { e Pão }\end{array}$ \\
\hline 5 & Conventional & 60,0 & Itariri & Nanicão \\
\hline 6 & Conventional & 30,0 & Miracatu & $\begin{array}{l}\text { GrandNaine, } \\
\text { Nanicão }\end{array}$ \\
\hline 7 & Conventional & 13,0 & Miracatu & Nanicão, Prata \\
\hline 8 & Conventional & 4,0 & Miracatu & Nanicão, Prata \\
\hline
\end{tabular}

Table 4 Interviewed agents on the first visit in the Vale do Ribeira, its localities and functionalities

\begin{tabular}{|c|c|c|}
\hline Agent $n^{\circ}$ & Functionality & City \\
\hline 1 & Secretary of Agriculture & Miracatu \\
\hline 2 & $\begin{array}{l}\text { City hall engineer agronomic and associate } \\
\text { at Cobam - "Comércio de Banana Ltda." }\end{array}$ & Miracatu \\
\hline 3 & $\begin{array}{l}\text { Retired director of CATI-"Coordenadoria } \\
\text { de Assistência Técnica Integral" }\end{array}$ & Registro \\
\hline 4 & Agronomist at CATI & Registro \\
\hline 5 & $\begin{array}{l}\text { General Secretary of ABAM-"Associação } \\
\text { de Bananicultrores de Miracatu" }\end{array}$ & Miracatu \\
\hline 6 & $\begin{array}{l}\text { President of AOVale-"Associação de } \\
\text { Agricultura Orgânica do Vale do Ribeira" }\end{array}$ & $\begin{array}{l}\text { Pedro de } \\
\text { Toledo }\end{array}$ \\
\hline 7 & Treasurer of AOVale & Iporanga \\
\hline 8 & General Secretary of Cobam & Miracatu \\
\hline 9 & Director of rural farmers union & Miracatu \\
\hline 10 & $\begin{array}{l}\text { Banana farmer and leader of quilombola } \\
\text { Ivaporanduva }\end{array}$ & Eldorado \\
\hline 11 & $\begin{array}{l}\text { Analyst of SEBRAE-"Serviço Brasileiro de } \\
\text { Apoio às Micro e Pequenas Empresas" }\end{array}$ & Registro \\
\hline 12 & $\begin{array}{l}\text { Banana trader and community leader of } \\
\text { Vila de Barra Funda }\end{array}$ & Miracatu \\
\hline 13 & Agronomist at "Defesa Agropecuária" & Registro \\
\hline 14 & Banana trader & São Paulo \\
\hline 15 & Banana trader & Santos \\
\hline 16 & Director of "Bananas Alexandre" & Guarulhos \\
\hline 17 & $\begin{array}{l}\text { Banana trader of SAVARI-"Sociedade } \\
\text { Agrícola Vale do Ribeira" }\end{array}$ & São Paulo \\
\hline 18 & Organic banana farmer & Sete Barras \\
\hline 19 & Proprietor of organic food sotre & São Paulo \\
\hline 20 & Banana trader of quilombola Ivaporanduva & Eldorado \\
\hline
\end{tabular}

Source: Elaborated by the authors.

A lack of means of communication appears as a significant social barrier to have a full participation on local food markets and an important dimension of the social isolation that marks the organic producer. ${ }^{27}$ Above all, it appears as challenge to reach other buyers who could offer a better price for organic banana. By the end of the day, organic producers exclusively depend on one single buyer, operating then under a clear monopsony situation. During our field research, we could identify their difficulty in accessing local food markets by witnessing the systematically losings of an expressive part of their harvest, mainly due to the impossibilities to sell it on the local market. ${ }^{28,29}$ On the other side, our qualitative findings also demonstrate a lack of economic capital among organic producers. When comparing to conventional farmers, organic ones have an 
expressive lower economic capital. This is evident when comparing the mean of propriety size between the two groups: as it is showed on table 4, presented in the attachments section, the mean size of an organic farm is 2.85 hectares, while the mean size of a conventional propriety is 26.75 hectares. In terms of organic farmers personnel trajectory, all of them told they chose this mode of production due to financial constraints to acquire pesticides and fertilizers. As a result, this pattern shows that organic producers in the regions are practitioners of the "organic agriculture of deny". 2

Above all, conventional producers benefit from a higher composition of capital, including instruments, equipment and resources that increase their social capital. ${ }^{30}$ Only one of the four conventional producers do not have full access to internet, while all of them have telephone lines and experience on rural association activities. Such conjecture contributes for a more complex and a more diverse network of buyers than the organic farmers. Therefore, instead of a monopsony, a scenario closer to the ideal type of free market was found among conventional banana producers.

Although producers did not reveal their annual net income, it is implicit that a low accessibility to local markets constrains the total revenue on organic proprieties. A primary consequence of this discrepancy of incomes between organic and conventional farmers can be felt on soil fertility. Fertility inputs on organic producers are expressively lower if compared to conventional ones: as the former does not add any quantity of fertilizers throughout the year, the latter use to add one round of fertility input in each four months. As a matter of a fact, it is not a coincidence that on Figure 1, fertility appears as a matter of higher concern among organic producers if compared to conventional ones. A straightforward consequence for such difference in terms of soil fertility is on the Sigatoka frequency of occurrence. A lack of fertility input among organic producers appears to be the main reason why this plague is more frequent among their banana plants than conventional producers, as it is shown on Figure 2. Despite the main challenges to enroll on local food markets and despite the negative consequences that it brings to the propriety in terms of fertility and control of plagues, all organic producers told that they are not willing to conduct a conventional system of production. More than a mere revelation of pesticides aversion, this statement also shows that organic producers believe that the control of Sigatoka is more effective through a correct adubation and fertilization than the using of chemicals pesticides. ${ }^{32}$

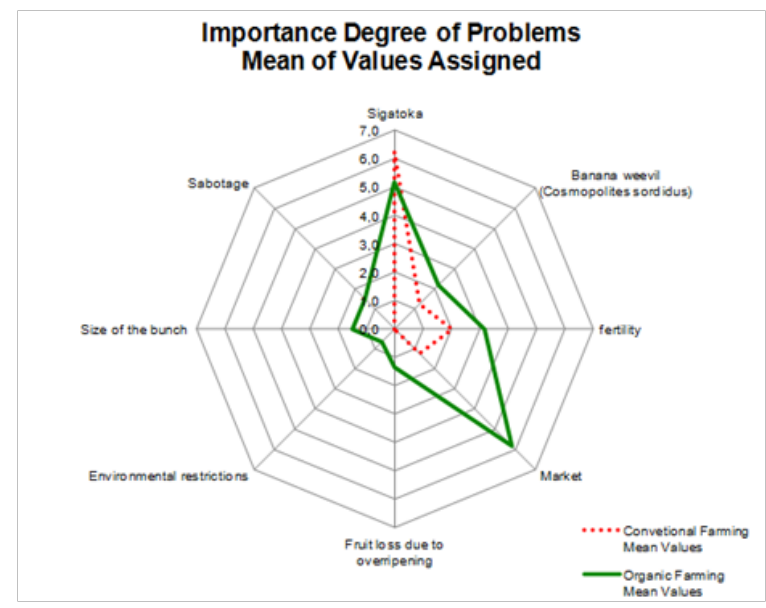

Figure I Main constraints and problems elected by the banana producers. The values for each of these problems are the average of grades, 0 - I0, given by producers.

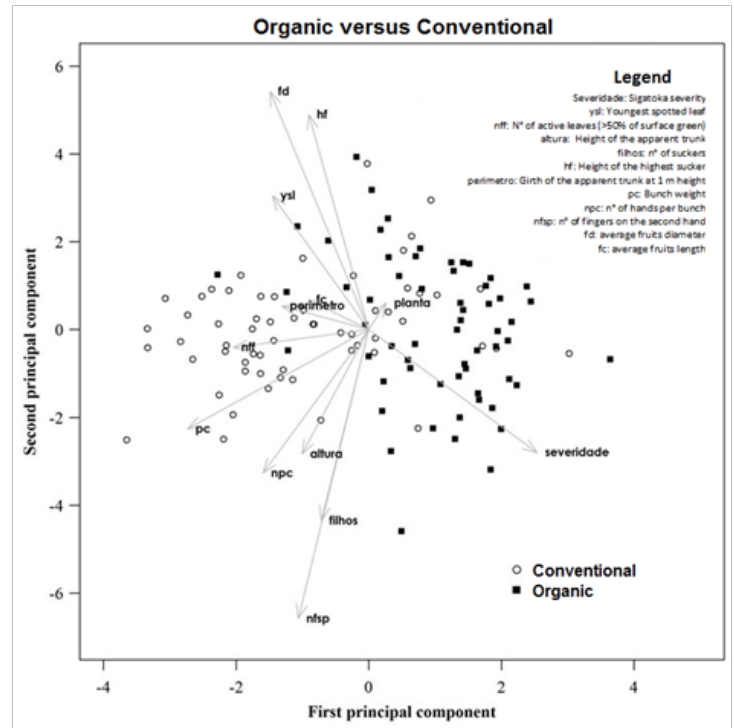

Figure 2 Main separation components, with organic agronomic components in black squares and conventional agronomic components in white circles. 


\section{Conclusion}

Although multiple challenges are presented to organic banana producers in the Vale do Ribeira, access to markets appears as the main barrier for the establishment of a sustainable organic production in the long term. The situation becomes clearer when one distinguish how different types of capital blunt the establishment of organic arrangements, noticing that not only economic capital is crucial to explain the low levels of organic output, but also social capital gives the tone to it. It is only through a higher accessibility on local food markets that organic producers shall receive a better price for their product and, with that, better profit rates. From this scenario, local organic farmers would be able to do constant fertility inputs, as it appears as an efficient strategy to control Sigatoka contamination. Reach a higher food security through organic practices passes through the establishment of a broad network of support, which may be able to mobilize instruments, equipment and resources to build up organic productive and commercial arrangements. Therefore, we think that this article may represent a valuable empirical case of how a lack of social and economic capital compromises the establishment of organic niches within the paradigmatic mode of functioning on agrarian markets in the developing world. Specifically regarding our case study, we think that non-governmental organizations and public agencies should consider the findings presented here to propose projects that support organic banana producers in Vale do Ribeira, especially through the mobilization of a broad support network for commercialization.

On the consumption side, consumers of organic banana should give room to different types of banana, instead of the usual ones like nanica, from the Cavendish group (AAA genome). Less known varieties, especially from genomic groups $\mathrm{AAB}$ and $\mathrm{ABB}$, are expressively more resistant to Sigatoka contamination than the conventional ones, representing an alternative of cultivation to organic producers, once they lack economic resources to do fertility inputs. However, the present article does not presents, nor it is final goal, ways to increase social capital among organic banana producers in order to build up market niches within the competitive food market of São Paulo state. In this sense, we hope that the presented case stimulate future research on collective action and social collaboration towards the construction of sustainable organic production and commercialization systems in developing countries. Studies on that direction would elucidate how organic markets can emerge as practical solutions for the most imminent challenges on people's food security, as well as clarifying how a broad network for support could sustain the emergence of alternative production and commercial chains in the rural world.

\section{Acknowledgments}

No.

\section{Conflicts of interest}

The author declares that there are no conflicts of interest.

\section{References}

1. Gliessman S. Agroecology: Growing the Roots of Resistance. Agroecology and Sustainable Food Systems Philadelphia. 2013;37(1):19-31.

2. Altieri MA. Agroecology: the science of natural resource management for poor farmers in marginal environments. Agriculture, Ecosystems and Environment, Amsterdam. 2002; 93(1):1-24.
3. IBGE. Censo Agropecuário. Brasil: Instituto Brasileiro de Geografia e Estatística; 2006.

4. IBGE. Regiões de Influência das Cidades. Braesil: Instituto Brasileiro de Geografia e Estatística; 2007.

5. Diegues ACO. O Vale do Ribeira e o litoral de São Paulo: meio ambiente, história e população. In: Setúbal MA, editor. Terra Paulista: trajetórias contemporâneas. São Paulo: Imprensa Oficial; 2008. 188p.

6. ISA, Instituto Socio-Ambiental. História e Economia. 2014.

7. Blazy JM, Carpentier A, Thomas A. The willingness to adopt agroecological innovations: Application of choice modelling to Caribbean banana planters. Ecological Economics, Amsterdam. 2011;72(3):140-150.

8. Henriques W, Jeffers RD, Lacher Jr, et all. Agrochemical use on banana plantations in latin america: perspectives on ecological risk Environmental Toxicology and Chemistry. 1997;16(1):91-99.

9. Altieri MA. Agroecologia: a dinâmica produtiva da agricultura sustentável. 5th ed. Porto Alegre: Editora Universidade/UFRGS; 2009. $117 \mathrm{p}$.

10. Fligstein N. Markets as Politics: A Political-Cultural Approach to Market Institutions. American Sociological Review. 1996;61(4):656-673.

11. Pierre Bourdieu. O Poder Simbólico. Lisboa: Difel; 1989. 314 P.

12. Pierre Bourdieu. Razões Práticas: sobre a teoria da ação. Campinas: Papirus Editora; 8th ed. 2008. 215 p.

13. Emirbayer M. Bourdieu and organizational analysis. Theory \& Society. 2008;37(1):1-44.

14. Fligstein N, Mcadam D. A Theory of Fields. Oxford: Oxford University Press; 2012. 256 p.

15. White HC. Markets from Networks: Socioeconomic Models of Production Princeton, NJ: Princeton Univ Press; 2002. Pp. 179-181.

16. Cochet $\mathrm{H}$. The systeme agraire concept in francophone peasant studies. Geoforum: Oxford. 2012;43(1):128-136.

17. Dufumier M. Agriculture Comparée Et Développement Agricole. Paris: Revue tiers monde; 2007. Pp.1-16.

18. Khatounian CA. A reconstrução ecológica da agricultura. Botucatu: Agroecologica; 2001. 345 p

19. Mazoyer M. Dynamique des Systèmes Agraires. Paris: Ministère de la Recherche et de La Technologie; 1987. 20p.

20. Mcardle BH, Anderson MJ. Fitting multivariate models to community data: a comment on distance-based redundancy analysis. Ecology, Washington. 2001;82(1):290-297.

21. MAPA. Ministério da Pecuária Agricultura e Abastecimento. Cadastro Nacional de Produtores Orgânicos. 2014.

22. Besanko DA, Braeutigam RR. Microeconomics. 12th ed. John Wiley \& Sons; 2012. pp. 703-732.

23. Bourdieu P. The forms of capital. In: Szeman I, Kaposy T, editors. Cultural Theory: an anthology. Wiley-Blackwell; 2010. 558 p.

24. Chaboussou F. Plantas doentes pelo uso de agrotóxicos. 1st ed. São Paulo: Expressão Popular; 2006. 323 p.

25. Faostat. Food and Agriculture Organization Statistics. 2013.

26. FIBL. Research Institute of Organic Agriculture. 2015.

27. Governo do estado de são paulo. “Conheça São Paulo".2016.

28. Roudart L. História das Agriculturas do Mundo: do neolítico à crise contemporânea. São Paulo: Editora UNESP; 2010. 568 p. 
29. Nicholson W, Snyder C. Intermediate Microeconomics and Its Application. 11th ed. Mason: South-Western, Cengage Learning; 2010. 898 p.

30. Nokoe S, Ortiz R. Optimum plot size for banana trials. Hortscience Alexandria. 1998;33(1):130-132.
31. Rodrigues AS, Guerreiro E, Miranda GM, et al. Enfoque Sistêmico em P \& D-A Experiência Metodológica do IAPAR. Circular IAPAR. Londrina: IAPAR; 1997. 109 p.

32. Varian HR. Intermediate Microeconomics: a modern approach. 8th ed. New York: Norton WW\& Company; 2010. 806 p. 